\title{
Diel cycles in viral infection of bacterioplankton in the North Sea
}

\author{
Christian Winter $^{1,2, *}$, Gerhard J. Herndl ${ }^{1}$, Markus G. Weinbauer ${ }^{1,3}$ \\ ${ }^{1}$ Department of Biological Oceanography, Royal Netherlands Institute for Sea Research, PO Box 59, 1790 AB Den Burg, \\ Texel, The Netherlands \\ ${ }^{2}$ Present address: Department of Limnology, Institute of Ecology and Conservation Biology, University of Vienna, \\ Althanstrasse 14, 1090 Vienna, Austria \\ ${ }^{3}$ Present address: Diversity, Biogeochemistry, and Microbial Ecology Group, Laboratoire d'Océanographie de Villefranche \\ (LOV), BP 28, 06234 Villefranche-sur-Mer, France
}

\begin{abstract}
Diel variations in substrate availability (largely due to variations in phytoplankton production) can lead to pronounced diel patterns in prokaryotic activity in the euphotic zone. We examined short-term changes in viral infection of bacterioplankton and its relation to bacterial activity in 3 distinct masses of North Sea surface waters marked by drifting buoys in June 2001 and April 2002. The water masses were sampled every 4 to $6 \mathrm{~h}$ for a period of 20 to $36 \mathrm{~h}$. The frequency of infected cells (FIC) estimated by a virus dilution approach varied from 5 to $64 \%$ at the western site, 17 to $55 \%$ at the southern site, and 10 to $22 \%$ at the northern site and was generally higher during the night than at daytime. Furthermore, FIC was negatively related to bacterial activity at all sites. Bacterial activity, measured via $\left[{ }^{14} \mathrm{C}\right]$-leucine incorporation, was ca. 1.5- to 5-fold higher during the day than at night. Our results indicate that viral lysis of bacteria occurs around noon to afternoon, and infection mainly during the night. Moreover, lysis and viral production seem to take place during high bacterial activity; this could be a strategy to increase the number of newly produced viruses.
\end{abstract}

KEY WORDS: Viral infection · Viral lysis $\cdot$ Bacteria $\cdot$ Frequency of viral infection Resale or republication not permitted without written consent of the publisher

\section{INTRODUCTION}

Viruses influence the cycling of organic carbon and nutrients in the ocean by constituting a significant source of mortality for phyto- and bacterioplankton (Wommack \& Colwell 2000). Using different approaches, it has been shown that the importance of viral infection for overall bacterioplankton mortality tends to increase with increasing bacterial abundance and/or productivity (e.g. Steward et al. 1992, Weinbauer et al. 1993, 2003, Tuomi et al. 1995, Noble \& Fuhrman 2000). More active bacterial cells may be more susceptible to viral infection than less active ones, and thus a more active bacterial community may sustain higher viral abundance (Steward et al. 1996, Corinaldesi et al. 2003). Furthermore, tidal mixing and flagellate grazing seem to increase the impact of viruses on bacterioplankton (Wilhelm et al. 2002,
Weinbauer et al. 2003). Other factors such as resistance to viral infection and the species composition of the host population influence the magnitude of viral infection as well; however, the importance of these factors for natural bacterial assemblages remains poorly understood.

Variations in bacterial production occur not only over a seasonal scale, but can be observed in the surface layer of the ocean on a diel scale as well. For phototrophic organisms, such diel cycles are a consequence of the diurnal light cycle; however, there is also evidence that heterotrophic prokaryotes display diel cycles in their activity. For example, Gasol et al. (1998) found a tight coupling between the photosynthetic extracellular release of organic material and its consumption by bacteria in the NW Mediterranean Sea. Similarly, Kuipers et al. (2000) reported that bacterioplankton growth was limited by nitrogen and phosphorus during the day and 


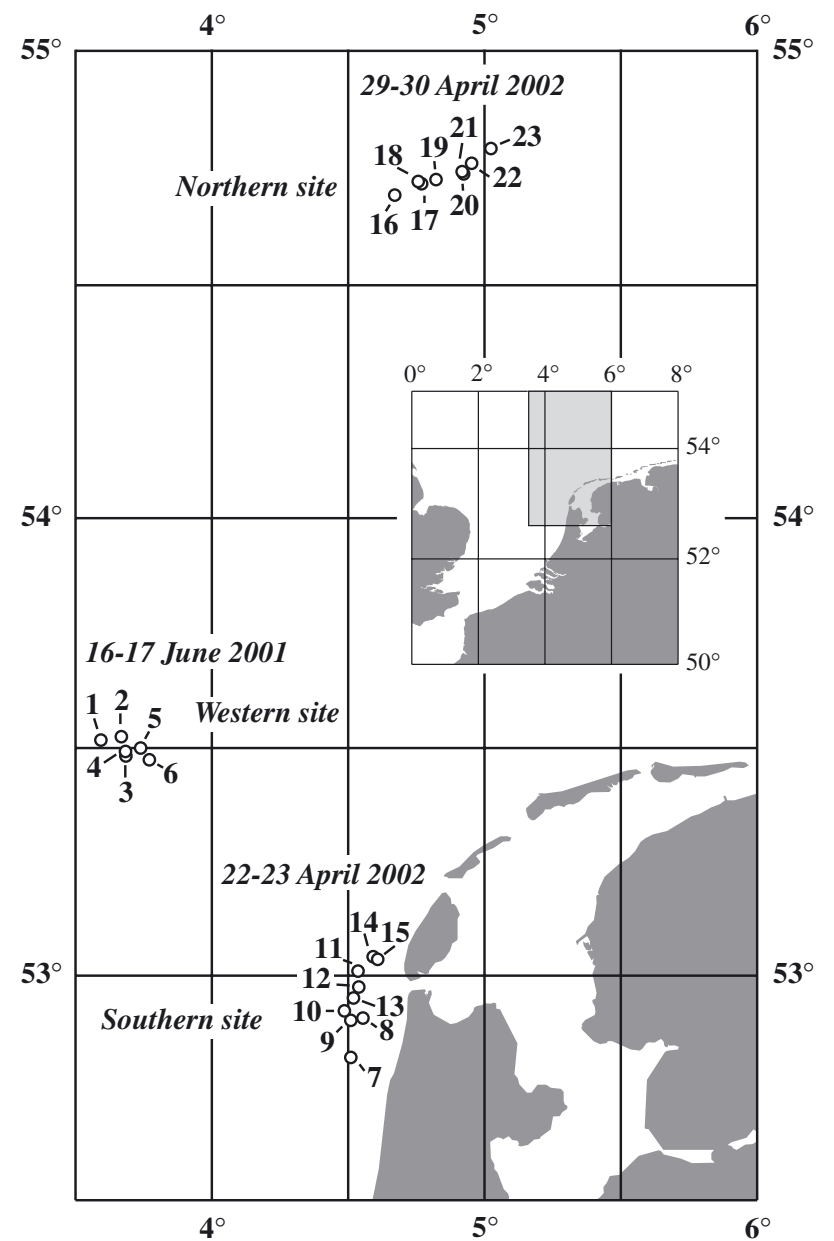

Fig. 1. Map of sampling sites where drifting buoys were deployed during cruises in June 2001 and April 2002. Dates and station numbers for western, southern and northern sites are indicated. Inset: North Sea with frame representing the study area

by the availability of dissolved organic carbon (DOC) during the night in the surface layers of the subtropical Atlantic Ocean, again implying a coupling of phytoplankton extracellular release and bacterial activity. These examples indicate that phyto- and bacterioplankton activity can change at the scale of hours, while cell abundance and biomass are often more constant. Such cycles result in efficient recycling mechanisms of carbon and nutrients within the microbial food web.

In situ studies assessing changes in microbiological processes at high temporal resolution are relatively rare, especially for virioplankton. Suttle \& Chen (1992) have argued that the concentration of infectious viruses should display a strong diel signal in surface waters due to sunlight-mediated viral decay. While a number of studies have found that total viral abundance in surface waters varies only moderately at the scale of hours to days (Wommack \& Colwell 2000), other authors have found more pronounced changes. For example, viral abundance increased within $2 \mathrm{~d}$ during a coastal phytoplankton bloom in the North Atlantic (Bratbak et al. 1990). By following a defined water mass in the northern Adriatic Sea, Weinbauer et al. (1995) found changes in viral and bacterial abundance that resembled predator-prey oscillations; however, no diel rhythm was observed. Bratbak et al. (1996) found significant temporal fluctuations of viral abundance in bottle incubations and in situ within 10 to $20 \mathrm{~min}$. Bettarel et al. (2002) reported diel periodicity in viral abundance and the frequency of visibly infected cells in the Bay of Villefranche (France, Mediterranean Sea) with highest values around 18.00 and $3.00 \mathrm{~h}$, respectively. Sampling of different water masses as a possible source for these variations, however, could not be ruled out in their study. All these studies indicate that elucidating the dynamics of viral infection of bacterioplankton and its role for bacteriamediated processes at the scale of hours is essential for a mechanistic understanding of microbial food webs.

By assuming a tight coupling of the flow of energy and matter between the different components of the microbial loop, several scenarios can be anticipated leading to diel cycles of viral infection in surface waters. For example, sunlight-induced loss of viral infectivity might relieve bacterioplankton from viral stress during the day. Also, diel changes in photosynthetic extracellular release of DOC and the photolytic cleavage of DOC by ultraviolet radiation might cause changes in bacterial activity (Pausz \& Herndl 1999, 2002), which, in turn, might affect viral infection of bacterioplankton. Such diel periodicity of viral infection and lysis has been suggested for cyanobacteria (Suttle 2000).

The goal of this study was to assess the short-term variability in viral infection of bacterioplankton in the surface layer of the North Sea by deploying drifting buoys to mark individual water masses. We found pronounced diel variations in viral infection of bacterioplankton in 3 masses of water whose bacterial activity differed by an order of magnitude.

\section{MATERIALS AND METHODS}

Sampling of distinct water masses. We conducted 2 cruises in the North Sea with RV 'Pelagia' in June 2001 and April 2002 (Fig. 1). A floating buoy with a drogue at $15 \mathrm{~m}$ depth was deployed to follow individual water masses over a period of 20 to $36 \mathrm{~h}$. In total, 3 buoy deployments were performed (subsequently referred to as 'western', 'northern', and 'southern site': Fig. 1). The western site was occupied in June 2001, the northern and southern sites in April 2002. Samples (20 1) from a depth of $5 \mathrm{~m}$ were collected using $10 \mathrm{l}$ NOEX- 
bottles mounted on a rosette, also holding the conductivity, temperature, and depth sensors.

Enumeration of bacteria and viruses. Samples $(2 \mathrm{ml})$ for the enumeration of bacteria and viruses in natural seawater samples and from the virus dilution incubations (described in later subsection) obtained during the cruise in June 2001 were fixed with formaldehyde ( $2 \%$ final concentration) and filtered onto $0.02 \mu \mathrm{m}$ filters (Whatman: Anodisc, $25 \mathrm{~mm}$ diameter) within $12 \mathrm{~h}$ after sampling. Bacterial cells and viral particles were stained on the filters using SYBR Green I (Molecular Probes) and enumerated with a Zeiss Axiophot microscope equipped for epifluorescence microscopy as described in Noble \& Fuhrman (1998). A minimum of 25 fields or 300 bacteria and viral particles were counted per filter. Bacteria and viruses from the virus dilution incubations of the cruise in April 2002 were enumerated using flow cytometry. Samples $(2 \mathrm{ml})$ were fixed with glutaraldehyde ( $0.5 \%$ final concentration) and frozen in liquid nitrogen. Bacterial cells and viral particles were stained with SYBR Green I (Molecular Probes) and enumerated with a FACSCalibur flow cytometer (Becton Dickinson) after dilution in TE buffer (10 mM Tris, 1 mM EDTA, pH 8.0) at an event rate of 100 to $800 \mathrm{~s}^{-1}$ (Marie et al. 1999, Brussaard et al. 2000). A total of at least 10000 events were recorded for each sample. Comparison between the bacterial and viral abundances obtained by epifluorescence microscopy and flow cytometry for the April 2002 cruise (data not shown) indicated that both methods yield similar results as reported previously (Marie et al. 1999).

Determination of the burst size. An aliquot of the bacterial concentrate $(5 \mathrm{ml}$, obtained by tangential flow filtration as described in later subsection) was fixed with formaldehyde ( $2 \%$ final concentration) and stored at $4^{\circ} \mathrm{C}$ until further processing. Bacterial cells were centrifuged onto Formvar-coated copper grids in a swing-out rotor at $4500 \times g$ and $4^{\circ} \mathrm{C}$ for $1 \mathrm{~h}$. Transmission electron microscopy was used to estimate the sample-specific burst size as the average number of viral particles in all visibly infected bacteria (Weinbauer et al. 1993). At least 10 visibly infected cells per sample were used to estimate the burst size.

Bacterial activity assessed by leucine incorporation into bacteria. Bacterial activity was measured by the incorporation of $\left[{ }^{14} \mathrm{C}\right]$-leucine $(10 \mathrm{nM}$ final concentration) on duplicate samples, and 1 formaldehyde-killed blank ( $2 \%$ final concentration) served as control (Kirchman et al. 1985). After incubation in the dark at in situ temperature for $1 \mathrm{~h}$, formaldehyde was added ( $2 \%$ final concentration) to the duplicate samples to terminate leucine incorporation. Thereafter, the samples were filtered through $0.45 \mu \mathrm{m}$ filters (Millipore; HAWP, $25 \mathrm{~mm}$ diameter) and rinsed twice with $10 \mathrm{ml}$ of ice-cold 5\% trichloroacetic acid. Subsequently, bac- terial leucine incorporation was determined by liquid scintillation counting.

Determination of FIC, viral production, and viral decay. We filtered $20 \mathrm{l}$ of seawater through $0.8 \mu \mathrm{m}$ pore-size filters (Millipore; Isopore ATTP, $142 \mathrm{~mm}$ diameter) using a stainless-steel filterholder (Sartorius) and an air-pressure pump (Verder; CONTEX-SOT. The $<0.8 \mu \mathrm{m}$ fraction was concentrated to a final volume of ca. $600 \mathrm{ml}$ using tangential-flow filtration (Millipore; Pellicon filter-cassette PTGVPPC05, $0.22 \mu \mathrm{m}$ pore-size, stored in $1 \mathrm{~N} \mathrm{HCl}$ between sampling stations). The filtrate of this ultrafiltration step was further processed using a spiral-wound ultrafiltration cartridge with a molecular weight cut-off of $30 \mathrm{kDa}$ (Amicon; S10Y30, stored in $0.1 \mathrm{~N} \mathrm{NaOH}$ between sampling stations) to obtain a virus-free ultrafiltrate and a virus concentrate with a final volume of ca. $600 \mathrm{ml}$. Both ultrafiltration devices were operated using peristaltic pumps (Watson \& Marlow: 604S) at a maximum pressure of $2 \mathrm{bar}$. The airpressure pump and the tubings were soaked in $1 \mathrm{~N} \mathrm{HCl}$ and rinsed with virus-free ultrafiltrate (molecular weight cut-off of $30 \mathrm{kDa}$ ) before use. The entire filtration procedure was performed at in situ temperature within 1 to $2 \mathrm{~h}$ after collecting the sample.

We used a previously described virus dilution approach to measure viral production (Wilhelm et al. 2002) and FIC (Weinbauer et al. 2002). Briefly, $2 \mathrm{ml}$ of the bacterial concentrate were added to $50 \mathrm{ml}$ of virus-free ultrafiltrate obtained from the same water sample, corresponding to about $50 \%$ of the original bacterial abundance. At the same time, $2 \mathrm{ml}$ of the virus concentrate were added to $50 \mathrm{ml}$ of virus-free ultrafiltrate to measure viral decay during the experiments in April 2002. Subsamples were taken to enumerate bacteria and viruses at regular intervals ( 4 to $6 \mathrm{~h}$ ) for a total period of up to $24 \mathrm{~h}$. The experiments were performed in duplicate at in situ temperature in the dark. Reducing viral abundance in the incubations increases the accuracy of counting and thus allows for the detection of minute changes in viral abundance against a reduced background. More importantly, this dilution in the virus dilution experiments reduces the probability of viruses encountering and infecting the bacterial host. Thus, an increase in viral abundance during the incubation period can be attributed to previous infection events in the natural environment. Differences in viral abundance were assumed to be significant if the ranges of duplicate incubations did not overlap between successive time points (e.g. Fig. 2A). FIC, as \% of total cells, was calculated according to the formula:

$$
\text { FIC }=\left\{\left[\left(V_{\max }-V_{\min }\right) / \text { burst size }\right] / B_{0}\right\} \times 100
$$

where $B_{0}$ is the bacterial abundance at the beginning of the experiment and $V_{\max }$ and $V_{\min }$ are the highest 


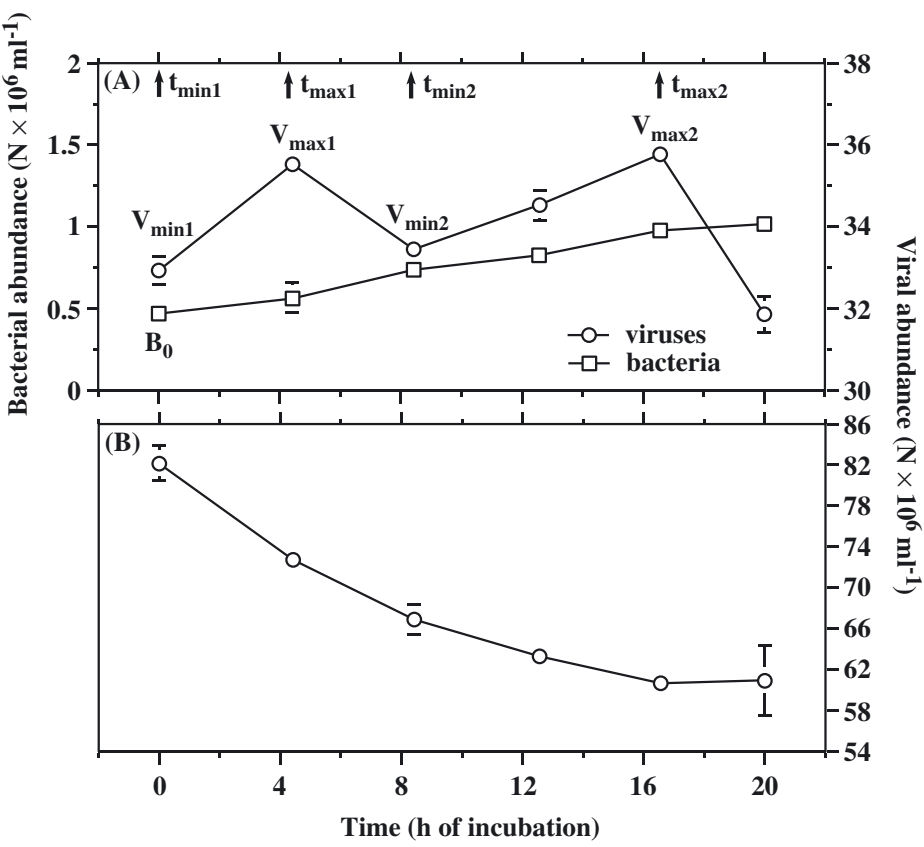

Fig. 2. (A) Example of development of bacterial and viral abundance over time in the virus dilution approach (Stn 10; 22 April 2002 at $52^{\circ} 55^{\prime} \mathrm{N}$ and $4^{\circ} 29^{\prime} \mathrm{E}$ ), showing bacterial abundance at start of the incubation $\left(B_{0}\right)$, viral abundances $\left(V_{\min 1}, V_{\max 1}, V_{\min 2}, V_{\max 2}\right)$ and corresponding time points $\left(t_{\min 1}, t_{\max 1}, t_{\min 2}, t_{\max 2}\right)$ used to calculate frequency of infected cells (FIC) and viral production. (B) Example of development of viral abundance over time during incubation of viruses in absence of bacteria to estimate viral decay (Stn 10). Average of duplicate incubations. Error bars represent range; when absent they were smaller than width of symbol

and lowest viral abundances, respectively, encountered during the course of the incubation. If the time course of viral abundance exhibited 2 peaks (e.g. Fig. $2 \mathrm{~A}_{\text {; from }} V_{\min 1}$ to $V_{\max 1}$ and from $V_{\min 2}$ to $V_{\max 2}$ ), then total FIC at the time of sampling was calculated by adding both FIC values, assuming that both peaks resulted from the lysis of bacterial cells already infected at the start of the experiments. Arguments supporting this assumption are presented in the 'Discussion'. Viral production was calculated as the slope between $V_{\min }$ and $V_{\max }$. For experiments in which 2 peaks in viral abundance occurred (e.g. Fig. 2A), viral production was calculated according to the formula:

$$
\begin{aligned}
& \text { viral production }= \\
& \qquad\left[\left(V_{\max 1}-V_{\min 1}\right)+\left(V_{\max 2}-V_{\min 2}\right)\right] /\left(t_{\max 2}-t_{\min 1}\right)
\end{aligned}
$$

where $t=$ time. Viral decay $\mathrm{h}^{-1}$ (Fig. 2B) for the southern and the northern site of buoy deployment was calculated as the slope of a linear least-squares regression fitted to the natural logarithm of viral abundance plotted against time (Suttle \& Chen 1992). However, the decay rates could not be used to correct the viral production measurements for reasons given in the 'Discussion'.

To allow a direct comparison of the data on a diel scale it was necessary to compensate for the differences in the time of sunrise and sunset between the stations (geographical position and date). Thus, the exact time of sunrise and sunset for each individual station was calculated using the astronomical software package 'xephem' (Clear Sky Institute; Version 3.5.2). Subsequently, this information was used to adjust the time scale for each sampling station to a 'standard day' with sunrise at 06:00 $\mathrm{h}$ and sunset at 18:00 h.

Correlation analysis. Spearman rank correlation coefficients were calculated to test the relationships between the parameters. Prior to analysis, the data were log-transformed except for FIC. Correlation coefficients with $\mathrm{p} \leq 0.05$ were assumed to be statistically significant.

\section{RESULTS}

\section{Physical characteristics of water masses}

The variations in salinity and temperature during the course of diel sampling were rather small at the western (salinity: 33.9 to 34.1 ; temperature: 12.3 to $12.7^{\circ} \mathrm{C}$ ) and northern (salinity: 34.3 to 34.4 ; temperature: 8 to $8.4^{\circ} \mathrm{C}$ ) sites, suggesting that distinct masses of water were sampled. The relatively large variation in salinity (31.2 to 32.5$)$ and temperature $\left(9.2\right.$ to $\left.10^{\circ} \mathrm{C}\right)$ at the southern site, however, indicates mixing of this water mass with surrounding water masses during sampling.

\section{Bacterial parameters}

Bacterial abundance averaged $1.2 \times 10^{6} \mathrm{ml}^{-1}(\mathrm{SD}=$ $\left.0.3 \times 10^{6}\right)$ at the western site, $1.5 \times 10^{6} \mathrm{ml}^{-1}(\mathrm{SD}=0.3 \times$ $\left.10^{6}\right)$ at the southern site, and $0.6 \times 10^{6} \mathrm{ml}^{-1}(\mathrm{SD}=0.1 \times$ $10^{6}$ ) at the northern site. Mean leucine incorporation into bacteria was $7.0 \mathrm{nmol}^{-1} \mathrm{~d}^{-1}(\mathrm{SD}=1.1)$ at the western site, $29 \mathrm{nmol} \mathrm{l}^{-1} \mathrm{~d}^{-1}(\mathrm{SD}=7.6)$ at the southern site, and $3.3 \mathrm{nmol} \mathrm{l}^{-1} \mathrm{~d}^{-1}(\mathrm{SD}=1.7)$ at the northern site. Thus, bacterial abundance and leucine incorporation were highest at the southern site and lowest at the northern site. Bacterial abundance displayed shortterm changes at the western and southern sites; however, no consistent diel oscillations were detectable (Fig. 3). In contrast, consistent diel variations were noticed for leucine incorporation at all sites (Fig. 4). Highest values of bacterial leucine incorporation were found around noon to early afternoon and lowest incorporation rates during the night (Fig. 4). 


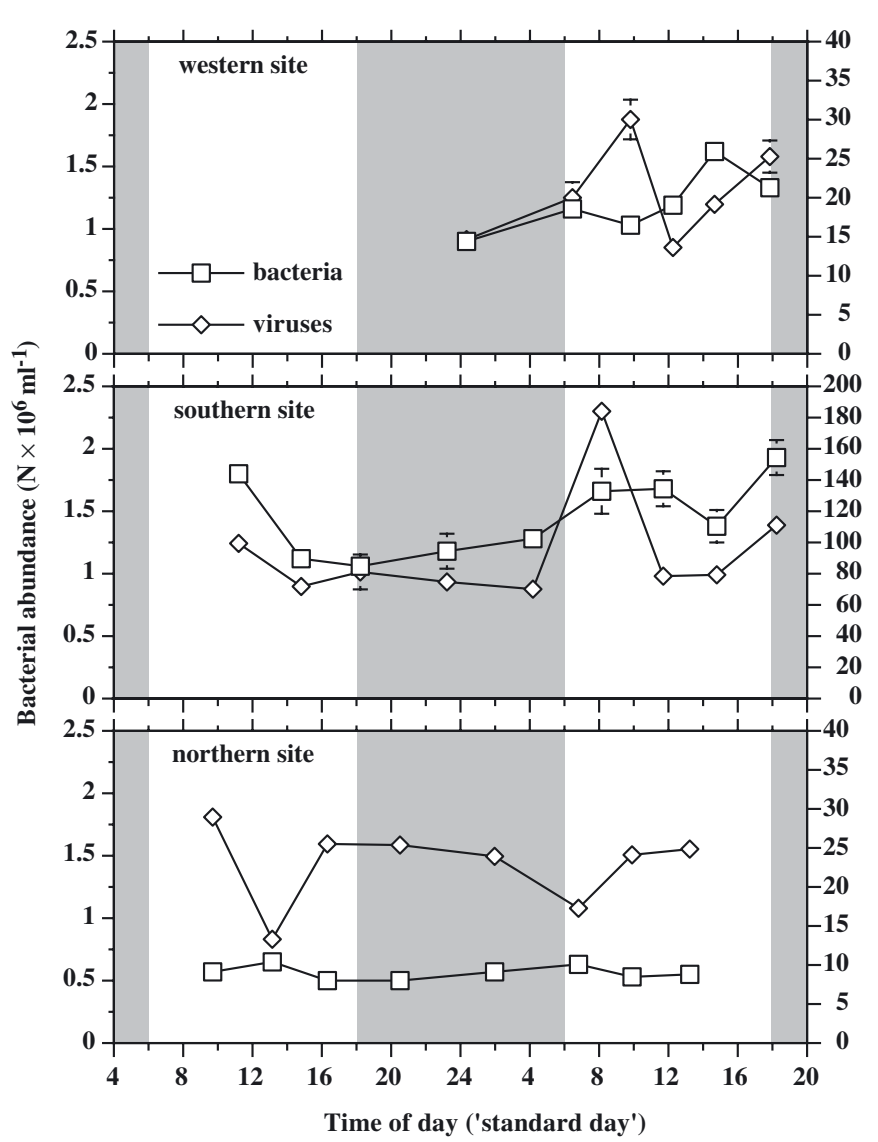

Fig. 3. Bacterial and viral abundance over time at western, southern, and northern sites. Error bars represent range of duplicate incubations; when absent they were smaller than width of symbol. Shaded areas correspond to dark period, and time scale was corrected for differences in times of sunrise and sunset

\section{Viral parameters}

Viral abundance averaged $21 \times 10^{6} \mathrm{ml}^{-1}(\mathrm{SD}=6 \times$ $\left.10^{6}\right)$ at the western site, $94 \times 10^{6} \mathrm{ml}^{-1}\left(\mathrm{SD}=36 \times 10^{6}\right)$ at the southern site, and $23 \times 10^{6} \mathrm{ml}^{-1}\left(\mathrm{SD}=5 \times 10^{6}\right)$ at the northern site. Viral abundance displayed short-term variations at all sites (Fig. 3). These oscillations, however, showed no consistent diel trend and no significant correlation was found between bacterial and viral abundance at the different sites (data not shown).

The FIC of bacterioplankton varied between 5 and $64 \%$ (mean 33\%) at the western site, between 17 and $55 \%$ (mean 29\%) at the southern site, and between 10 and $22 \%$ (mean 14\%) at the northern site. The FIC showed a consistent diel signal at all sites, with high values during the night and low values during the day (Fig. 4). This pattern was also observed when a constant burst size was used to calculate FIC (data not shown). At the western and southern site, FIC was ca. 6 times higher during the night than the day. At the northern site, FIC varied 2-fold over the day. Furthermore, FIC was negatively correlated with leucine incorporation at all sites. This relationship was statistically significant at the southern and northern sites (Spearman rank correlation: western site: $\mathrm{r}=-0.77, \mathrm{p}=$ 0.085 ; southern site: $r=-0.87, p=0.014$; northern site: $\mathrm{r}=-0.79, \mathrm{p}=0.038$ ).

Viral production averaged $20 \times 10^{4} \mathrm{ml}^{-1} \mathrm{~h}^{-1}(\mathrm{SD}=$ $\left.11 \times 10^{4}\right)$ at the western site, $51 \times 10^{4} \mathrm{ml}^{-1} \mathrm{~h}^{-1}(\mathrm{SD}=16$ $\left.\times 10^{4}\right)$ at the southern site, and $3 \times 10^{4} \mathrm{ml}^{-1} \mathrm{~h}^{-1}(\mathrm{SD}=2$ $\times 10^{4}$ ) at the northern site. Viral decay rates (Table 1 ) averaged $12 \times 10^{-3} \mathrm{~h}^{-1}\left(\mathrm{SD}=3 \times 10^{-3}\right)$ at the southern site and $8 \times 10^{-3} \mathrm{~h}^{-1}\left(\mathrm{SD}=3 \times 10^{-3}\right)$ at the northern site. The sample-specific burst size varied between 21 and 40 (mean 30) at the western site, between 17 and 28 (mean 21) at the southern site, and between 18 and 30 (mean 22) at the northern site. At each site, the burst size increased significantly with increasing leucine incorporation (Spearman rank correlation: western site: $r=0.94, p=0.035$; southern site: $r=0.91, p=0.010$; northern site: $r=0.91, p=0.017$ ).

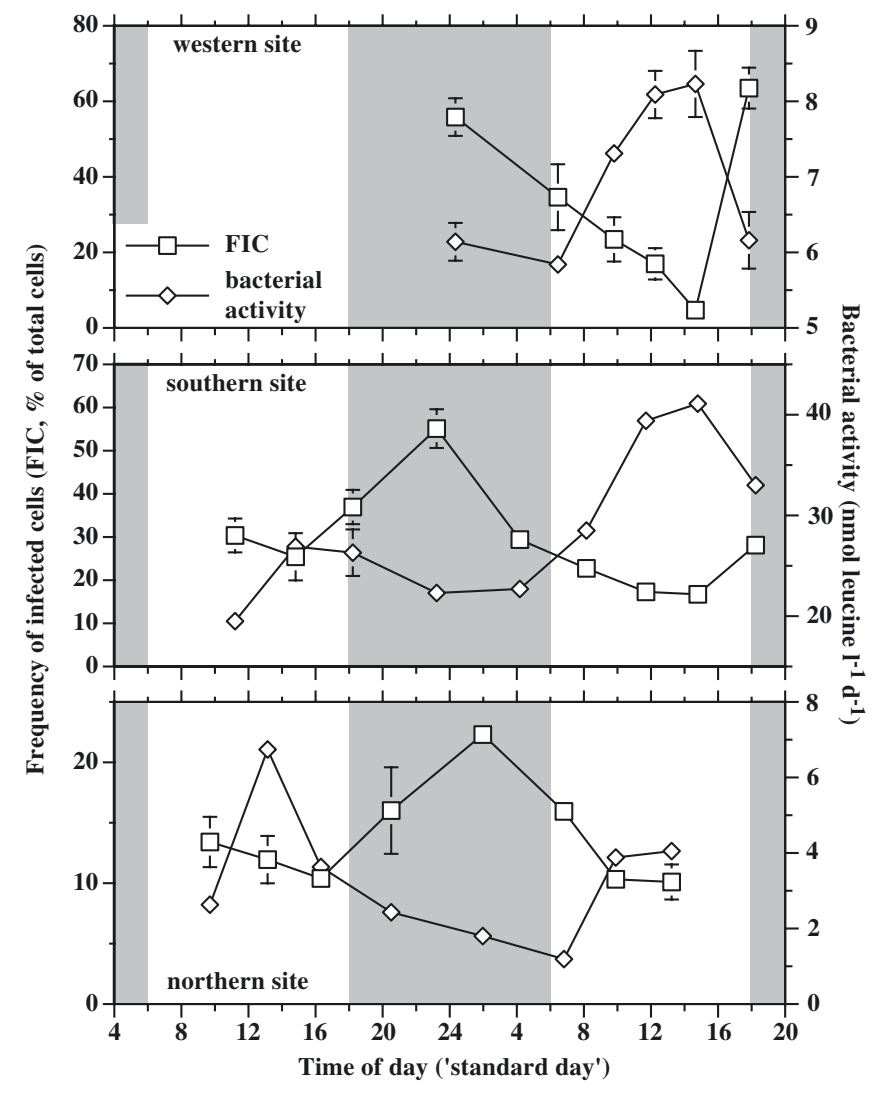

Fig. 4. Time course of bacterial activity (leucine incorporation) and frequency of infected cells (FIC) at western, southern and northern sites. Error bars represent range of duplicate incubations; when absent they were smaller than width of symbol. Shaded areas correspond to the dark period, and time scale was corrected for differences in the time of sunrise and sunset 
Table 1. Average and range of duplicate measurements of viral decay in April 2002. Decay rates calculated by plotting the natural logarithm of viral abundance versus time and fitting a linear least-squares regression line to the data, of which $\mathrm{r}^{2}$ is shown; the slope of this regression is the decay rate $\mathrm{h}^{-1}$. Additionally, time of sampling, as corrected for differences between sites in the time of sunrise and sunset, is given. Time of day = 'standard day' with sunrise at 06:00 h and sunset at 18:00 h. nm: not measured

\begin{tabular}{|ccccc|}
\hline Stn & $\begin{array}{c}\text { Time of } \\
\text { day }(\mathrm{h})\end{array}$ & $\begin{array}{c}\text { Viral decay } \\
\left(\times 10^{-3}\right)\end{array}$ & $\begin{array}{c}\text { Range } \\
\left(\times 10^{-3}\right)\end{array}$ & $\mathrm{r}^{2}$ \\
\hline $\begin{array}{c}\text { Southern site } \\
7\end{array}$ & & & & \\
8 & 11.12 & 10 & 10 & 0.935 \\
9 & 14.49 & 10 & $9-10$ & 0.710 \\
10 & 18.13 & 12 & $11-13$ & 0.958 \\
11 & 23.13 & 17 & $16-17$ & 0.960 \\
12 & 4.11 & 13 & $12-14$ & 0.926 \\
13 & 8.09 & 12 & 12 & 0.945 \\
14 & 11.42 & 15 & $11-19$ & 0.967 \\
15 & 14.47 & 12 & $11-12$ & 0.926 \\
Northern site & 18.14 & 7 & $6-8$ & 0.978 \\
16 & & & & \\
17 & 09.42 & 3 & $1-4$ & 0.864 \\
18 & 13.08 & 8 & $7-9$ & 0.810 \\
19 & 16.19 & $\mathrm{~nm}$ & $\mathrm{~nm}$ & $\mathrm{~nm}$ \\
20 & 20.31 & $\mathrm{~nm}$ & $\mathrm{~nm}$ & $\mathrm{~nm}$ \\
21 & 01.58 & 8 & $7-9$ & 0.857 \\
22 & 06.49 & 11 & $9-13$ & 0.707 \\
23 & 09.54 & 10 & $9-10$ & 0.630 \\
& 13.14 & $\mathrm{~nm}$ & $\mathrm{~nm}$ & $\mathrm{~nm}$ \\
\hline
\end{tabular}

\section{Time-dependent variation in viral abundance during incubation}

Viral abundance in each incubation was normalized to a mean of zero and unity variance to compensate for the absolute differences in viral numbers between the incubations (Fig. 5). Such a presentation allows comparison of the dynamics in viral abundance between incubations, but does not allow assessment of the magnitude of viral production due to the normalization. The development of viral abundance between consecutive incubations was remarkably similar with respect to the time of day when highest and lowest viral abundances were detected, especially for the western and the southern site (Fig. 5). For example, in the incubations sampled at 15.00 and $19.00 \mathrm{~h}$ at the southern site (Fig. 5), highest viral abundance was recorded at the same time of day, i.e. at $8.00 \mathrm{~h}$, despite the $4 \mathrm{~h}$ difference in sampling. This suggests that lysis in the 2 consecutive incubations occurred at the same time of day and originated from the same infection event. However, exceptions to this trend existed, e.g. at the southern site in the incubations sampled at 15:00 and 19:00 h viral abundance was highest during the day, while in incubations sampled at the same time the next day it was highest during the night (Fig. 5).

\section{DISCUSSION}

\section{Critical evaluation of the virus dilution approach}

The virus dilution approach has been used to assess viral impact on bacterioplankton in a number of different marine environments (Weinbauer et al. 2002, Wilhelm et al. 2002) as well as in 2 rivers (Hewson et al. 2001). Furthermore, Weinbauer et al. (2002) presented evidence for the robustness of the method over a range of dilution rates, and showed that the concentration procedure as used in this study and the previously used filtration procedure to dilute viruses involving a washing step (Wilhelm et al. 2002) yield similar results. Using the virus dilution approach, Wilhelm et al. (2002) found steadily increasing viral numbers over the course of the incubations, while in the present study viral abundance displayed 1 or 2 peaks (Fig. 2A). One explanation for this difference between the 2 studies might be the lack of a diel signal of viral infection and/or lysis at the study site of Wilhelm et al. (2002) (Discovery Passage and Strait of Georgia, Canada). Another possibility could be the shorter incubation times ( $9 \mathrm{~h}$ ) in their study compared to the 20 to $24 \mathrm{~h}$ in this study. In some of our incubations, however, viral abundance decreased initially for 4 to $8 \mathrm{~h}$ or remained stable before it increased (Fig. 5). A delay in the production of viruses using the virus dilution approach has also been reported for the Gulf of Mexico (Weinbauer \& Suttle 1999).

The occurrence of 2 peaks in viral abundance in most of our incubations (Fig. 5) is a potential problem when calculating FIC values. Since viral lysis during the incubation was assumed to be the result of previous viral infection of bacteria, the FIC values of both peaks were added to calculate FIC at the time of sampling. We cannot completely exclude the possibility that the second peak in viral abundance was due to new infection and lysis; however, 3 arguments can be put forward against this: (1) Bacterial and viral numbers averaged $53 \%$ (range: $36-78 \%$ ) and $35 \%$ (range: 14-56\%), respectively, of the in situ abundance at the start of the incubations. This dilution of viruses resulted in decreased cell-specific contact rates by, on average, $60 \%$ compared to in situ conditions as calculated using the model of Murray \& Jackson (1992), and thus should have reduced the chance of new infection. (2) Peaks in viral abundance generally occurred at the same time of day in consecutive incubations started at 4 to $6 \mathrm{~h}$ intervals (Fig. 5). This cannot have been caused by new infection events during the incubations, since then peaks in viral abundance in consecutive incubations should occur with a 4 to $6 \mathrm{~h}$ difference in time. (3) Assuming that the viral latent period equals bacterial generation time (Proctor et al. 1993, Binder 1999) 
Western site

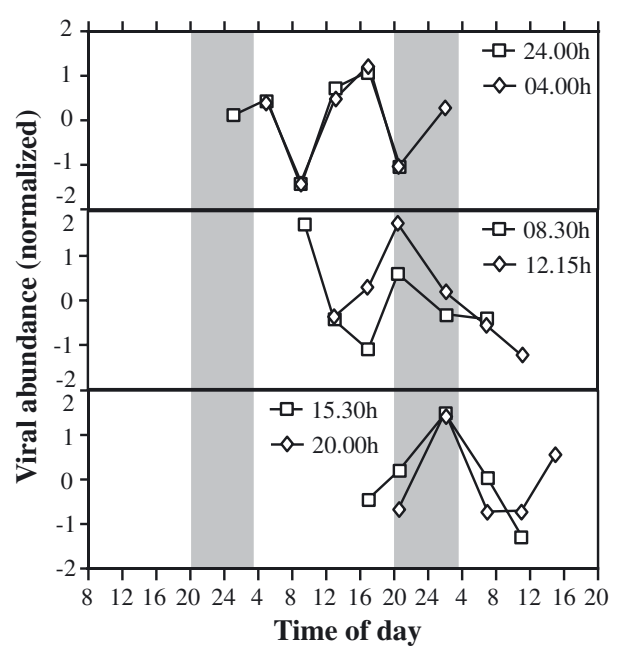

Southern site

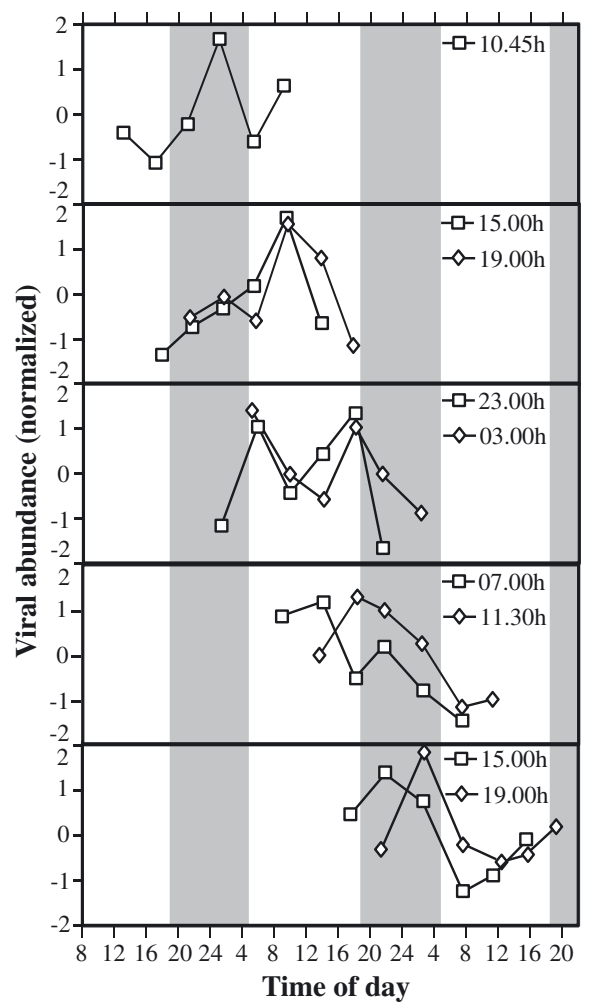

Northern site

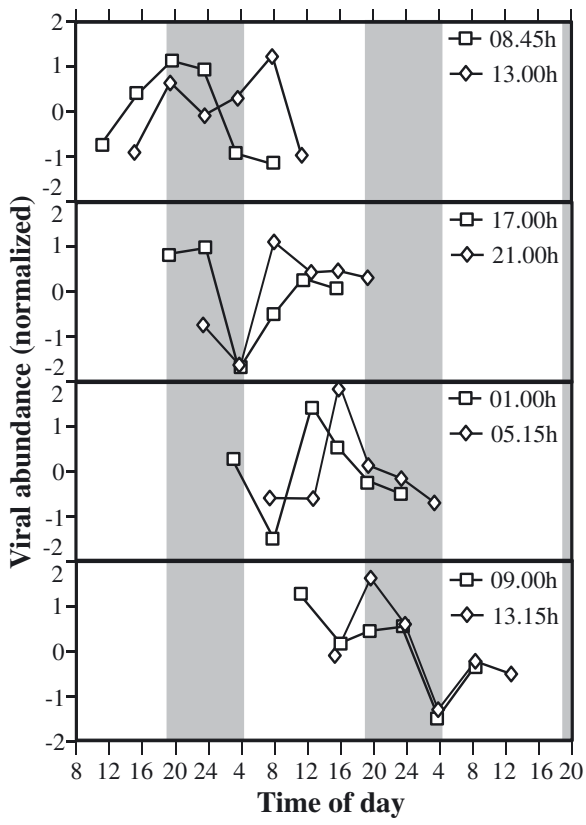

Fig. 5. Viral abundance over time in the virus dilution approach at western, southern, and the northern sites, showing normalized average values of duplicate incubations plotted against sampling time in coordinated universal time (UTC). Difference between the sampling time and start of incubations corresponds to time needed to process the sample. Shaded areas represent dark period; error bars are not shown for sake of clarity

and given the relatively long bacterial generation times at the western and northern sites (western site: $2.2 \mathrm{~d}_{\text {; }}$ southern site: $0.7 \mathrm{~d}$; northern site: $2.8 \mathrm{~d}$ ), no measurable increase in viral abundance as a result of new infection should occur at incubation times of 20 to $24 \mathrm{~h}$. The 2 peaks in viral abundance could result from different viral populations with different latent periods, from different virus-host systems if the hosts are growing at different rates, and/or from 2 different infection events prior to collecting the samples for incubation.

In case 2 peaks in viral abundance were recorded during the incubations, viral production rates were calculated by adding the net increase of Peak 1 to the net increase of Peak 2 divided by the time elapsed between the start of the incubations and the second peak (Fig. 2A). Thus, presenting viral production for a specific time point is problematic and was not attempted in this study.

Major causes of viral decay such as sunlight (Suttle \& Chen 1992), non-specific adsorption of viruses by $\mu \mathrm{m}$ sized particles (Murray \& Jackson 1992, Suttle \& Chen 1992) and dissolved organic matter of high molecular weight (>30 kDa; Noble \& Fuhrman 1997) were excluded from our approach by incubating in the dark and by the filtration step, respectively. However, we observed a strong decrease in viral abundance in almost all incubations (Fig. 5). The discontinuous nature of viral lysis in the incubations (Fig. 5) suggests that viral decay in the incubations was discontinuous as well. For instance, viruses released during a specific lysis event might be subject to low decay during an initial 'resistance phase' and then enter a 'decay phase'. The high variability in decay rates measured in incubations by adding virus concentrates to cell-free water at the southern and northern sites (Table 1) would support this idea. For this reason and because viral decay rates were integrated over 20 to $24 \mathrm{~h}$, they could not be used to correct the viral production rates in this study.

\section{Diel cycles in leucine incorporation by bacteria}

The small variations in salinity and temperature at the western and northern sites suggest that distinct water masses were sampled. Thus, the changes in leucine incorporation are rather a consequence of a 
diel pattern in bacterial activity than of sampling different water masses. In contrast, mixing at the southern site (as indicated by the changes in salinity) could have masked the diel dynamics of leucine incorporation at this site. However, the similarity in the time course of leucine incorporation between all the sites (Fig. 4) would argue against a strong effect of mixing of different water masses on bacterial activity. Also, the dynamics of the diel cycle in bacterial activity might be stronger than the effect of mixing and result in detectable diel oscillations despite mixing of water masses at this site.

Diel cycles in bacterial leucine incorporation similar to those found in the present study were observed previously, and might be due to phytoplankton extracellular release (Gasol et al. 1998, Kuipers et al. 2000) and/or the photolytic activity of ultraviolet radiation enhancing the bioavailability of DOC (Obernosterer \& Herndl 2000). An alternative explanation can be inferred from the finding that a significant fraction of bacterial cells was infected at all the sites and that high values of FIC were followed by high values of bacterial leucine incorporation (Fig. 4). Since viral lysis can enhance bacterial activity through the release of bioavailable DOC from the lysed cells (Fuhrman 1999, Wommack \& Colwell 2000, Middelboe \& Lyck 2002), the uptake of lysis products could have caused or amplified the diel cycle in bacterial activity.

\section{Diel cycles in viral infection}

Viral infection frequency, estimated as frequency of visibly infected cells using transmission electron microscopy in the study of Bettarel et al. (2002) and as FIC by the virus dilution approach in our study, was higher by night than by day (Fig. 4). This suggests a diel cycle in viral infection of bacterioplankton. Furthermore, the discovery of such a diel signal in the oligotrophic Bay of Villefranche (Bettarel et al. 2002) and in areas of the North Sea with different levels of bacterial activity indicates that this might be a common phenomenon. In contrast to the study of Bettarel et al. (2002) conducted in Mediterranean waters, we did not find any consistent diel pattern in viral abundance at our study sites (Fig. 3).

Due to the problems in assigning viral production to exact time points and the lack of diel cycles in viral abundance, it is difficult to estimate the time points of major lysis events. The data shown in Fig. 5 indicate that viral lysis occurs throughout the entire day; however, FIC data suggest that a diel cycle of viral lysis might be involved as well. Thus, lowest values of FIC should roughly correspond to major lysis events. If this holds true, highest viral production rates should occur around noon to early afternoon. Diel variations in the frequency of visibly infected cells and in situ viral abundance in the Mediterranean Sea (Bettarel et al. 2002) lead to a similar conclusion. However, lysis events as indicated by the peaks in in situ viral abundance would occur in the late afternoon in this environment.

Several mechanisms, which are not mutually exclusive, might cause a diel cycle of viral infection. For example, prophage induction due to sunlight-induced DNA damage or to increased cell activity (Wilson \& Mann 1997) could have resulted in a diel cycle in FIC. It is unlikely, however, that sunlight-induced prophage induction was involved in the diel changes of FIC, since sunlight seems to be a poor inducing agent (Jiang \& Paul 1996, Weinbauer \& Suttle 1999). Moreover, FIC was negatively related to bacterial activity at all our study sites, and correlation analysis of cellspecific bacterial activity with FIC yielded essentially the same results (data not shown). Thus, we have no evidence that prophage induction by increased bacterial activity was responsible for the diel cycle in FIC.

Daily variations in bacterial activity may also result in a corresponding diel cycle in FIC. For example, elevated bacterial activity might increase the susceptibility of bacteria to viral infection, since more active bacteria might express more receptors for nutrients, potentially serving also as receptors for virus attachment (Wommack \& Colwell 2000). However, the negative correlation between FIC and bacterial activity argues against this explanation. In contrast, major lysis events seem to roughly co-occur with high bacterial activity (as discussed above). Thus, our study does not provide evidence that bacterial activity is a driving force of viral infection of bacterioplankton on a diel scale, but bacterial activity might promote lysis. It is beneficial for viruses to lyse a cell when it is active, since this would increase the number of progeny and hence the probability of new infection. This conclusion is supported by the finding that the burst size estimates increased with increasing bacterial production.

The low infection frequencies found during the day in our study might result from sunlight-induced losses of viral infectivity in surface waters during the light period (Suttle \& Chen 1992). This may even hold true in the presence of light-dependent DNA repair, since photoreactivation, although a powerful DNA repair mechanism (Wilhelm et al. 1998), cannot restore infectivity to all damaged viruses (Weinbauer et al. 1997). Staying within the host cell during most of the light period would be beneficial for viruses since (1) they can exploit the DNA repair mechanisms of the hosts and their own repair mechanisms would be activated by the host metabolism, (2) viruses released in the afternoon should have an increased survival rate by 
avoiding or at least reducing sunlight-induced DNA damage, and (3) readily bio-available DOC derived from either photosynthetic extracellular release or the increased bioavailability of DOC by ultraviolet radiation might provide the carbon and energy necessary for viral replication.

Based on the results of this study, we propose the following hypothetical scenario for the diel variation in viral infection and lysis of heterotrophic bacterioplankton in the surface layer of the sea. Viral lysis should occur predominantly around noon to early afternoon when bacterial activity is highest resulting in high numbers of infectious viral particles. The progeny viruses released in the afternoon accumulate less DNA damage than viral lysis in the morning. Thus, viral infection should be highest during the night. After infection, viral replication continues during the day. This hypothetical scenario is similar to that proposed for cyanobacteria (Suttle 2000). However, cyanobacteria depend directly on sunlight for photosynthesis, and thus the coupling between the daily light cycle, cyanobacterial activity and cyanophage proliferation should be much tighter than for heterotrophic bacteria. The lack of a consistent diel pattern in viral abundance (Fig. 3) does not support our hypothetical scenario. Since the current methods do not allow differentiation between infectious and non-infectious viral particles, we might have missed diel dynamics of infectious viral particles. Similarly, bacteria showed no diel pattern in abundance (Fig. 3) but varied regularly with respect to activity (Fig. 4). In general, activity parameters vary more strongly than abundance parameters and, thus, are more likely to reveal dynamic patterns such as diel variations. It seems problematic to combine the coordinated viral infection and lysis pattern with the existence of highly diverse viral communities (Breitbart et al. 2002). However, a broader host range than previously assumed (Jensen et al. 1998) could explain this discrepancy. Moreover, bacteria concentrated in 'hot spots' such as nutrient plumes around phytoplankton cells (Azam 1998) may suffer from higher infection frequencies and be responsible for the diel variability in viral infection of bacterioplankton. Clearly, more research is needed to evaluate the proposed hypothetical scenario of viral infection and lysis of bacterioplankton.

\section{Implication}

A direct implication of diel variations in FIC is that estimates of virus-induced mortality of bacterioplankton depend on the time of day the samples are taken, and this should be taken into account when studying viral dynamics in situ. Also, most approaches used to estimate virus-induced mortality of bacterioplankton are based on a steady-state assumption (e.g. Noble \& Steward 2001). Diel cycles in viral infection and bacterial activity violate this assumption, indicating that viral impact of bacterioplankton estimated by these methods has to be considered cautiously.

One of the most important effects of viral lysis in terms of flow of energy and matter is to convert particulate organic carbon into DOC and stimulating bacterial activity by reducing the amount of organic carbon available to higher trophic levels such as heterotrophic nanoflagellates (Fuhrman 1999). In systems such as the North Sea, with high viral and bacterial abundance and a strong viral impact on bacterioplankton, a diel cycle in viral infection and lysis should strengthen the coupling between DOC production and bacterial consumption.

Acknowledgements. The authors thank the captain and crew of RV 'Pelagia' for their service at sea. We thank the chief scientists M. Baars and C. P. D. Brussaard for the opportunity to join their cruises. The help of M. Pérez and T. Reinthaler in handling part of the bacterial production measurements and of A.C. Baudoux with the flow cytometer is greatly acknowledged. The authors acknowledge 3 anonymous reviewers for improving the manuscript with their comments. Funding for this study was provided by the Dutch Science Foundation (NWO-ALW grant 809.33.004; the cruises were funded by NWO-ALW grants 835.20.004 and 811.33.002). This work is in partial fulfillment of the requirements for a $\mathrm{PhD}$ degree from the University of Groningen by C.W.

\section{LITERATURE CITED}

Azam F (1998) Microbial control of oceanic carbon flux: the plot thickens. Science 280:694-696

Bettarel Y, Dolan JR, Hornak K, Lemée R and 5 others (2002) Strong, weak, and missing links in a microbial community of the N.W. Mediterranean Sea. FEMS Microbiol Ecol 42: 451-462

Binder BJ (1999) Reconsidering the relationship between virally induced bacterial mortality and frequency of infected cells. Aquat Microb Ecol 18:207-215

Bratbak G, Heldal M, Norland S, Thingstad TF (1990) Viruses as partners in spring bloom microbial trophodynamics. Appl Environ Microbiol 56:1400-1405

Bratbak G, Heldal M, Thingstad TF, Tuomi P (1996) Dynamics of virus abundance in coastal seawater. FEMS Microbiol Ecol 19:263-269

Breitbart M, Salamon P, Andresen B, Mahaffi JM, Segall AM, Mead D, Azam F, Rohwer F (2002) Genomic analysis of uncultured marine viral communities. Proc Natl Acad Sci USA 99:14250-14255

Brussaard CPD, Marie D, Bratbak G (2000) Flow cytometric detection of viruses. J Virol Methods 85:175-182

Corinaldesi C, Crevatin E, Negro PD, Marini M, Russo A, Fonda-Umani S, Danovaro R (2003) Large-scale distribution of virioplankton in the Adriatic Sea: testing the trophic state control hypothesis. Appl Environ Microbiol 69:2664-2673

Fuhrman JA (1999) Marine viruses and their biogeochemical and ecological effects. Nature 399:541-548 
Gasol JM, Doval MD, Pinhassi J, Calderón-Paz JI, GuixaBoixareu N, Vaqué D, Pedrós-Alió C (1998) Diel variations in bacterial heterotrophic activity and growth in the northwestern Mediterranean Sea. Mar Ecol Prog Ser 164: $107-124$

Hewson I, O'Neil JM, Fuhrman JA, Dennison WC (2001) Virus-like particle distribution and abundance in sediments and overlying waters along eutrophication gradients in two subtropical estuaries. Limnol Oceanogr 46: $1734-1746$

Jensen EC, Schrader HS, Rieland B, Thompson TL, Lee KW, Nickerson KW, Kokjohn TA (1998) Prevalence of broadhost-range lytic bacteriophages of Sphaerotilus natans, Escherichia coli, and Pseudomonas aeruginosa. Appl Environ Microbiol 64:575-580

Jiang SC, Paul JH (1996) Occurrence of lysogenic bacteria in marine microbial communities as determined by prophage induction. Mar Ecol Prog Ser 142:27-38

Kirchman DL, K'Ness E, Hodson RE (1985) Leucine incorporation and its potential as a measure of protein synthesis by bacteria in natural aquatic systems. Appl Environ Microbiol 49:599-607

Kuipers B, Noort GJv, Vosjan J, Herndl GJ (2000) Diel periodicity of bacterioplankton in the euphotic zone of the subtropical Atlantic Ocean. Mar Ecol Prog Ser 201: $13-25$

Marie D, Partensky F, Vaulot D, Brussaard CPD (1999) Enumeration of phytoplankton, bacteria, and viruses in marine samples. In: Robinson JP, Darzynkiewicz Z, Dean PN, Orfao A, Rabinovitch PS, Stewart CC, Tanke HJ, Wheeless LL (eds) Current protocols in cytometry. John Wiley \& Sons, New York, p 11.11.11-11.11.15

Middelboe M, Lyck PG (2002) Regeneration of dissolved organic matter by viral lysis in marine microbial communities. Aquat Microb Ecol 27:187-194

Murray AG, Jackson GA (1992) Viral dynamics: a model of the effects of size, shape, motion and abundance of singlecelled planktonic organisms and other particles. Mar Ecol Prog Ser 89:103-116

Noble RT, Fuhrman JA (1997) Virus decay and its causes in coastal waters. Appl Environ Microbiol 63:77-83

Noble RT, Fuhrman JA (1998) Use of SYBR Green I for rapid epifluorescence counts of marine viruses and bacteria. Aquat Microb Ecol 14:113-118

Noble RT, Fuhrman JA (2000) Rapid virus production and removal as measured with fluorescently labeled viruses as tracers. Appl Environ Microbiol 66:3790-3797

Noble RT, Steward GF (2001) Estimating viral proliferation in aquatic samples. Methods Microbiol 30: p 67-84

Obernosterer I, Herndl GJ (2000) Differences in the optical and biological reactivity of the humic and nonhumic dissolved organic carbon component in two contrasting coastal marine environments. Limnol Oceanogr 45: $1120-1129$

Pausz C, Herndl GJ (1999) Role of ultraviolet radiation on phytoplankton extracellular release and its subsequent utilization by marine bacterioplankton. Aquat Microb Ecol 18:85-93

Pausz C, Herndl GJ (2002) Role of nitrogen versus phosphorus availability on the effect of UV radiation on bacterio-

Editorial responsibility: Gunnar Bratbak,

Bergen, Norway plankton and their recovery from previous UV stress. Aquat Microb Ecol 29:89-95

Proctor LM, Okubo A, Fuhrman JA (1993) Calibrating estimates of phage-induced mortality in marine bacteria: ultrastructural studies of marine bacteriophage development from one-step growth experiments. Microb Ecol 25: 161-182

Steward GF, Wikner J, Cochlan WP, Smith DC, Azam F (1992) Estimation of virus production in the sea: 2. Field results. Mar Microb Food Webs 6:79-90

Steward GF, Smith DC, Azam F (1996) Abundance and production of bacteria and viruses in the Bering and Chukchi Seas. Mar Ecol Prog Ser 131:287-300

Suttle CA (2000) Ecological, evolutionary, and geochemical consequences of viral infection of cyanobacteria and eukaryotic algae. In: Hurst CJ (ed) Viral ecology. Academic Press, San Diego, CA, p 247-296

Suttle CA, Chen F (1992) Mechanisms and rates of decay of marine viruses in seawater. Appl Environ Microbiol 58: 3721-3729

Tuomi P, Fagerbakke KM, Bratbak G, Heldal M (1995) Nutritional enrichment of a microbial community: the effects on activity, elemental composition, community structure and virus production. FEMS Microbiol Ecol 16:123-134

Weinbauer MG, Suttle CA (1999) Lysogeny and prophage induction in coastal and offshore bacterial communities. Aquat Microb Ecol 18:217-225

Weinbauer MG, Fuks D, Peduzzi P (1993) Distribution of viruses and dissolved DNA along a coastal trophic gradient in the Northern Adriatic Sea. Appl Environ Microbiol 59:4074-4082

Weinbauer MG, Fuks D, Puskaric S, Peduzzi P (1995) Diel, seasonal, and depth-related variability of viruses and dissolved DNA in the Northern Adriatic Sea. Microb Ecol 30: $25-41$

Weinbauer MG, Wilhelm SW, Suttle CA, Garza DR (1997) Photoreactivation compensates for UV damage and restores infectivity to natural marine virus communities. Appl Environ Microbiol 63:2200-2205

Weinbauer MG, Winter C, Höfle MG (2002) Reconsidering transmission electron microscopy based estimates of viral infection of bacterioplankton using conversion factors derived from natural communities. Aquat Microb Ecol 27: 103-110

Weinbauer MG, Christaki U, Nedoma J, Šimek K (2003) Comparing the effects of resource enrichment and grazing on viral production in a meso-eutrophic reservoir. Aquat Microb Ecol 31:137-144

Wilhelm SW, Weinbauer MG, Suttle CA, Jeffrey WH (1998) The role of sunlight in the removal and repair of viruses in the sea. Limnol Oceanogr 43:586-592

Wilhelm SW, Brigden SM, Suttle CA (2002) A dilution technique for the direct measurement of viral production: a comparison in stratified and tidally mixed coastal waters. Microb Ecol 43:168-173

Wilson WH, Mann NH (1997) Lysogenic and lytic viral production in marine microbial communities. Aquat Microb Ecol 13:95-100

Wommack KE, Colwell RR (2000) Virioplankton: viruses in aquatic ecosystems. Microbiol Mol Biol Rev 64:69-114

Submitted: October 16, 2003; Accepted: January 20, 2004

Proofs received from author(s): May 3, 2004 